\title{
Sustainable Practices in International Chain Hotels in Muscat, Sultanate of Oman
}

\author{
Abdulmajeed Al Ghazali', Bianca Zaloumis ${ }^{2}$, Firdouse Rahman Khan ${ }^{3}$ \\ ${ }^{12}$ Oman Tourism College, ${ }^{3}$ Sohar University \\ Email: ${ }^{1}$ Abdulmajeed.ghazali@gmail.com, ${ }^{2}$ bianca.zaloumis@ otc.edu.om, ${ }^{3}$ firdouse4u@ $@$ co.uk
}

Article History: Received on $9^{\text {th }}$ Feb. 2021, Revised on $7^{\text {th }}$ Mar. 2021, Published on $1^{\text {st }}$ Apr. 2021

\begin{abstract}
Purpose: The aims of the study were to analyse the sustainable practices adopted by international chain hotel brands in Muscat; to analyse and find out the extent of the sustainable practices affecting guest satisfaction in international chain hotels in Muscat and to determine the barriers and challenges faced by international hotel chain brands in Muscat.

Design/methodology/approach: Forty questionnaires were distributed to two chain hotels' employees in different job positions. In-depth interviews were also used to gather qualitative information from human resources departments and corporate social responsibility specialists to discuss the current trends in sustainable practices in international chain hotel brands in Muscat. The collected data was then analyzed using SPSS and Qualitative tools.

Findings: The study reveals that the hotels' sustainability initiatives had an effective impact on cost savings and helps to reduce waste, and resource wastage. It was also found that guests are willing to pay more at the hotel to support their green initiatives and the guests were satisfied with the innovation towards the sustainability initiatives undertaken and felt their stay a memorable one.

Research implications: It was observed that there is a strong relationship between sustainable green practices and guest satisfaction and so maintain the sustainable practices to raise to the guest expectations. Some of the guests were not aware of the sustainable practices and the employees and the creation of awareness is a must.

Social implications: Awareness within the staff and the community can be raised only through proper education and training.

Originality/Value: The study confines to international chain hotels located in Muscat, the capital of Sultanate of Oman. The study excludes the economic and social aspects of sustainability as the entire focus was on the environmental aspects of sustainable practices only.
\end{abstract}

Keywords: Sustainable Green Practices, International Chain Hotels, Local Community, Eco-friendly, Environmentally-friendly, Guest Satisfaction.

\section{Introduction}

The tourism sector has become a catalyst source of the country's income, its contribution to the hotel industry is enormous (Leonidou et al., 2013). Tourism is a sector with continuous hope, along with it are multiple socio-economic benefits and a wide range of influences on manifold sectors (WTO \& UNDP, 2017). Tourism has huge value in the global economy, and the industry keeps on providing various opportunities to anyone who can be involved in tourism to contribute to sustainability.

The term sustainability is considered a crucial element in society. It is not only the hospitality or the hotel industry which gets affected by the phenomena of sustainability but the entire global community. With the advancement of technology, some hoteliers are starting to think sustainably not only in pushing and encouraging multinational companies, corporations, and firms to focus on the environment in general but also on corporate social responsibility (CSR) as it makes a positive impact on the hotel industry and the guests in terms of experiencing a new social life for them (Rakická, 2016).

Van Rheede and Blomme (2012) claimed that the notion of sustainability is usually based on the concept of concentrating on the environment, society, and economy when making decisions. In reality, hoteliers habitually concentrate on the environment, but they frequently neglect the economic and social aspects. As responsible management, the hotels should help in creating economic opportunities and positive forces to the environment in a sustainable manner (Marriott, 2015). Not only do the hoteliers focus more on the environment, but customers also show the same preference.

The potential impact of worldwide tourism growth on the environment has become a hot topic within the hospitality industry (Zurburg et al., 1995). Oliveira et al. (2016) postulated that the social pressure had forced the hotels to start looking into the environmental impacts. Lunkes and Rosa (2012) claimed that 
environmental planning and control aim to provide effective hotel operations so that the hotel can respond to legal requirements, achieve its environmentally sustainable practices, meet the demands, and achieve its strategies and goals as well.

As a result, knowing to what extent the hoteliers can contribute to the environment is exceptionally crucial.

Table 1 Stakeholders Interest in the Sustainable Environment of Hotels

\begin{tabular}{|l|l|}
\hline \multicolumn{1}{|c|}{ Stakeholders } & \multicolumn{1}{c|}{ Interests in the environmental information } \\
sustomers and & $\begin{array}{l}\text { Services and facilities of environmental efficiency should be provided to } \\
\text { customers and suppliers. } \\
\text { Customers may have other objectives before environmental concerns such as } \\
\text { quality of service, price and the uniqueness of hospitality, etc. }\end{array}$ \\
\hline $\begin{array}{l}\text { Employees } \\
\text { and unions }\end{array}$ & $\begin{array}{l}\text { Policies of the environment, observation of the unions, environmental } \\
\text { training, on job qualification, well experienced and highly skilled } \\
\text { employees. }\end{array}$ \\
\hline
\end{tabular}

Source: (Lunkes \& Rosa, 2012)

\section{Research Questions}

During the research study on sustainable environment, the following questions raised:

1. What sustainable strategies have been adopted by international chain hotels in Muscat?

2. Is there a relationship between sustainable practices and levels of guest satisfaction in hotels in Muscat?

3. What are the issues and challenges faced by an international chain hotel in Muscat in implementing sustainable practices?

\section{Research Objectives}

In line with the above research questions, the following research objectives were defined:

1. to analyze the sustainable practices adopted by international chain hotel brands in Muscat

2. to analyse and find out the extent of the sustainable practices affecting guest satisfaction in international chain hotels in Muscat to determine the barriers and challenges faced by international hotel chain brands in Muscat.

\section{Significance of the study}

The developing trends in the hotel industry help the chain hotels in Muscat to build the reputation of the hotels through image building and providing job opportunities thereby supporting the national economy. Knowing the challenges and barriers faced by the hotel industry will help hoteliers to identify gaps, and strategize proper marketing tactics.

The study deals with the sustainable practices in international chain hotel brands and the current challenges faced by them. The study creates awareness of stakeholders of the international hotel chain brands in Muscat regarding the sustainable practices adopted. The study benefits hoteliers and hotel managers to come up with new ideas to assist in decision-making among international hotel chains in Muscat. In addition to that, the study brings awareness among the local people to involve themselves in the hotel industry by offering local products. Most importantly, this study is beneficial to the hoteliers because the discussion possesses insights on the importance and the ways on how to perform the green practices in daily operations and implementing CSR initiatives.

Tourism is suffering and undergoing deep changes due to the involvement of the internet playing a crucial role in defining its market (y Patiño et al., 2016). Tourism and the hospitality industry facing different types of challenges than ever before potentially harming the environment and the local economies (Bukva, 2009). The sustainable practices and the introduced sustainable strategies meant for them having an impact on the hotels form the basic reason for this study.

\section{Review of literature \\ Green Practices}

The environmental management system needs to be integrated within a company using the concepts of reuse, recycling, replacement, reducing, recycle, etc. to achieve environmental sustainability (Middleton \& Hawkins, 1998). The awareness of environmental significance has increased among the government, stakeholders, and the public over the last two decades. (De Grosbois, 2012). Hotels all over the world have also started implementing green practices in their daily operations (Yadav et al., 2016). Butler Rosebury 
\& Partners Architects (2016) pointed out that most of the travellers while booking hotels look for the environment and more eco-friendly choices and most of the hotels are shifting towards green approaches like conservation of energy and water etc. Bruns-Smith et al. (2015) mentioned that hoteliers are entirely conscious of the advantages of environmental sustainability and most of them promote resource conversation.

Green marketing business deals with decreasing waste, saving energy, environmentally friendly, and encourages sustainability of the society and environmental health (Rahman et al., 2012). Green marketing aims at promoting, pricing, and distributing products/services that shall not damage the environment (Jain \& Kaur, 2004). Pickett-Baker and Ozaki (2008) assured that the concept of green marketing leads the hotels to provide green products for their guests. Green marketing involves three phases viz. ecological marketing, environmental marketing, and sustainable marketing (Peattie, 2001). Environmental marketing aims to minimize and reduce any environmental damage and turns green initiatives into a competitive advantage (Katrandjiev, 2016).

Due to green marketing, consumers have been concerned with eco-friendly practices (Manaktola \& Jauhari, 2007). Foster et al. (2000) claimed that the demand of guests makes the hospitality sector maintain and attain environmental performances. Chan (2013) found that hotels have implemented the concepts to promote the green image and attract the green market due to influential competition. Chan (2009) argued that green marketing campaigns likely to raise awareness of a hotel's commitment to fulfilling its environmental responsibilities.

\section{Sustainable Practices}

Sustainability has become a key factor in representing comfort within the hospitality and tourism sector (Rosa \& Silva, 2017). Jayawardena, Pollard, Chort, et al. (2013) identified that the significance of guest's engagement through sustainable efforts, encourage the guest to from the localized food products. Chikita (2012) found that there existed a positive relationship between sustainable practices and the extent of guest satisfaction, as sustainable practices of green hotels consist of relaxing peaceful environment and weather to the guests.

As far as sustainability in the hospitality industry, the key aspects to consider are waste, water, energy, recycling, and green purchasing, etc.(Jones et al., 2014; Legrand et al., 2016). Berezan et al. (2010) added that hotels implementing sustainable practices were not only raising awareness of natural environment protection but the monetary benefits of the hotel's income as well. Revilla et al. (2001) claim that hotels adopting a lot of green approaches such as recycling, purchasing local products in implementing sustainable practices which influence guests to experience local produce and to reuse/recycle the natural cleaning products and baths or by reducing waste conserving energy and water. Hotels have been reacting to the phenomenon of sustainable activities such as reducing energy reduction, water consumption, etc. (Lorenc, $\underline{2016}$.

One of the ways to encourage guests to spend the least time in the bath is to keep a timer in the shower to monitor the time spent (Järvensivu, 2014). The UK's Environment agency assured that hotels could reduce the amount of consuming water per guest per night by up to $50 \%$ (Tuppen, 2013). Educating the guests and employees of the hotels will help to contribute to the conservation of energy through innovative methods (Hitchcock et al., 2009). As an energy conservation measure, hotels have started using the card key system wherein all the electrical and electronic appliances get turned off automatically as soon as the guest leaves the room, thereby conserving electrical energy (Legrand et al., 2016). Oggeide (2012) assured that guests expect environmental features and the hotels need to maintain environmental attributes to meet the guest's expectations.

One of the most complicated challenges to adopt sustainable practices into hotels and resorts is the inadequate labor supply and for the best implementation of sustainable practices, the employees should be committed and have a full awareness of the significance of implementing social sustainability practices (Jayawardena, Pollard, Caira, et al., 2013). The Canadian Tourism Research Institute and The Conference Board of Canada (2012) claimed that labor is scarce in the hospitality industry. Berezan et al. (2010) stated that the hospitality industry had been facing pressure by the government regulation and legislation to introduce sustainable practices which may affect the country's reputation.

Tourists' lack of awareness might negatively impact/damage the ecosystem like the rainforests and coral reefs etc. which will in turn reduce the number of visitors (Holden, 2016). The social awareness on environmental issues has forced some companies to move from a reactive to a proactive environmental 
attitude which enabled competitive advantage (Bagur-Femenias et al., 2016). Several studies implied that employees who are proactive in the hospitality industry always perform their jobs effectively and shaping their work environment (Seibert et al., 2001). Chan and Hawkins (2010) claimed that the contribution and motivation of staff with implementing the environmental management system emphasize the significance of environmental sustainability in hotels.

As Information and communication technologies (ICT) have become a crucial part of the hotel industry, major chain hotels have adopted ICT in addition to Social media (DiPietro \& Wang, 2010). Siguaw et al. (2000) and Stewart et al. (2004) suggested that the development and the implementation of information technology (IT) related applications will ease the booking and guest's experience as the technological processes for the environmental management through water, waste management, and energy alike. Most of the independent hotels have less access to innovative and sophisticated technology as its very important for hoteliers to communicate their green legitimacy (Kleinrichert et al., 2012).

Multicultural issues might not allow the hotel's company to follow and implement various sustainable practices (Korjala, 2012). Hoteliers should pay attention to the current trends of globalization and sustain the cultural attributes to reflect the requirement of the hometown towards it is operation and management (WANG \& Jing, 2009). According to Wheelen and Hunger (1998), a strong culture can form a positive basis for a competitive position globally with its unique experience to tourists.

\section{Corporate social responsibility (CSR) in Hotels}

As per the CSR pyramid for developing countries framed by Visser (2008), the economic responsibility of the hotel companies forms the basis of the CSR pyramid as without finance, companies cannot perform other responsibilities - legal, ethical, and philanthropic. But CSR in hotels is not for the economic indicators such as reaping benefits only but also in protecting the environment sustainably and improving social relationships thereby the reputation (Lorenc, 2016). If a hotel wants to fulfil CSR, it should act ethically and donate to the community (Grant et al., 2017). The responsibility of the hotels is to fulfil society's and customer's expectations (Heesbeen, 2014). CSR leads to increased customer satisfaction because most customers prefer to be served by the locals to feel the traditional touch (Luo \& Bhattacharya, 2006). Aaker (1996) claimed that satisfied customers are unlikely to change the brand as gradually they become loyal. Hotel companies depend on CSR to form brand loyalty, brand awareness, and most importantly to give their brands more visibility (Grover, 2014). Brammer et al. (2012) provided a clear understanding that CSR is positively related to the brand image.

\section{Research Methodology}

For this research study, questionnaires were prepared and distributed to gather data to find out the potential of adaptation by the international hotel chain brands in Muscat. The questionnaire was divided into four parts. All questions have been structured accordingly. The population of the study is confined to two chain hotels, Grand Hyatt and Intercontinental Hotels. A total of forty questionnaires were distributed among the mentioned hotel employees in different departments.

Additionally, in-depth interviews were also used to gather qualitative information from human resources departments and corporate social responsibility specialists to discuss the current trends in sustainable practices in international chain hotel brands in Muscat. Interview questions were utilized to gain information on the strategies of sustainable practices that can be adopted in hotels and to determine the issues and challenges faced by the hotels. During the interview, nine direct questions were asked to the hotelier. The questions were about the different types of sustainable initiatives practiced in a hotel; the reason for following such sustainable practices; ways on how to educate the employees and in-house guests about environmentally sustainable practices and challenges in such implementation of sustainable practices in the hotels. The data was obtained through the random distribution of guests in the two during June 2018 to July 2018.

The interview's findings supported the research to analyse the study's objectives based on sustainable practices adopted by international chain hotels in Muscat. 
Findings

Table 1 Details of the respondents

\begin{tabular}{|c|c|c|c|}
\hline & & Frequency & $\%$ \\
\hline \multirow{2}{*}{ Gender } & Male & 19 & 47.5 \\
\hline & Female & 21 & 52.5 \\
\hline \multirow{5}{*}{ Age } & Under 25 & 14 & 35.0 \\
\hline & $26-30$ & 12 & 30.0 \\
\hline & $31-35$ & 8 & 20.0 \\
\hline & $40-45$ & 5 & 12.5 \\
\hline & 46 and above & 1 & 2.5 \\
\hline \multirow{3}{*}{$\begin{array}{l}\text { Employment } \\
\text { status }\end{array}$} & Self-employed & 16 & 40.0 \\
\hline & $\begin{array}{l}\text { Employed } \\
\text { Private/Government }\end{array}$ & 24 & 60.0 \\
\hline & Others & 0 & 0.0 \\
\hline \multirow{3}{*}{ Type of Guest } & Omani citizen & 22 & 55.0 \\
\hline & Inbound tourist & 9 & 22.5 \\
\hline & $\begin{array}{l}\text { Expatriate/ Resident in } \\
\text { Oman }\end{array}$ & 9 & 22.5 \\
\hline \multirow{2}{*}{$\begin{array}{l}\text { Purpose of } \\
\text { Stay }\end{array}$} & Business & 16 & 40.0 \\
\hline & Vacation/ Leisure & 24 & 60.0 \\
\hline
\end{tabular}

Source: Questionnaire

Table 2 Factors that come to mind when they have an environmentally friendly hotel

\begin{tabular}{|l|c|c|}
\hline \multicolumn{1}{|c|}{ Factors on environmentally friendly hotel } & Frequency & \% \\
\hline Energy conservation e.g. Energy-saving lightings & 5 & 12.5 \\
\hline Water conservation, e.g., Rainwater harvesting & 4 & 10.0 \\
\hline Alternative energy sources e.g. Solar energy & 3 & 7.5 \\
\hline $\begin{array}{l}\text { Environmental consciousness, e.g., Use of recycled } \\
\text { materials }\end{array}$ & 2 & 5.0 \\
\hline Social or environmental education to guests & 3 & 7.5 \\
\hline Waste management e.g. Recycling materials & 3 & 7.5 \\
\hline Linen reuse policy & 0 & 0.0 \\
\hline Green procurement & 3 & 7.5 \\
\hline Communication of sustainability practices to the community & 12 & 30 \\
\hline Water-efficient appliances & 2 & 5.0 \\
\hline Usage of local products and supplies & 2 & 5.0 \\
\hline Green cleaning products & 1 & 2.5 \\
\hline
\end{tabular}

The table shows that the majority (30\%) of respondents declared that communication of sustainability practices to the community first comes to mind when they have an environmentally friendly hotel. $12.5 \%$ thought of energy conservation like energy-saving lightings, followed by water conservation (e.g., rainwater harvesting) at $10 \%$. On the other hand, only $5 \%$ thought of the usage of local products and suppliers and water-efficient appliances.

Table 3 Environmentally friendly initiatives identified by guests in hotels

\begin{tabular}{|l|c|c|}
\hline \multicolumn{1}{|c|}{ Initiatives } & Frequency & \% \\
\hline LEED Certification & 8 & 20.0 \\
\hline Linen Re-use program & 15 & 37.5 \\
\hline Energy Efficient Light Bulbs & 22 & 55.0 \\
\hline
\end{tabular}




\begin{tabular}{|l|c|c|}
\hline Energy Star Appliances & 17 & 42.5 \\
\hline Recyclable Paper Products & 14 & 35.0 \\
\hline Recycling Program & 23 & 57.5 \\
\hline Paperless Check-Out & 12 & 30.0 \\
\hline Water Saving Fixtures & 16 & 40.0 \\
\hline Usage of Solar Energy & 9 & 22.5 \\
\hline
\end{tabular}

When the respondents were asked to identify environmentally friendly initiatives they have seen from hotels recycling program emerged as the top answer with $57.5 \%$. It was closely followed by energy-efficient light bulbs with $55 \%$. Energy star appliances with $42.5 \%$, water-saving with fixtures $40 \%$, and linen re-use program with $37.5 \%$ clinched the top five initiatives ranked by the respondents. Among the listed initiatives, LEED certification ranked last with $20 \%$ only.

Table 4 Role of Sustainability in Providing Good Services and Products

\begin{tabular}{|c|c|c|c|}
\hline $\begin{array}{c}\text { Sustainable practices in hotels play a significant } \\
\text { role in providing good services and products }\end{array}$ & Frequency & $\%$ & Rank \\
\hline Yes & 37 & $92.5 \%$ & 1 \\
\hline No & 3 & $7.5 \%$ & 2 \\
\hline
\end{tabular}

The majority $(92.5 \%)$ of the respondents agreed that sustainable practices in hotels play a significant role in providing excellent services and products, while only $7.5 \%$ think otherwise.

Table 5 Hotel Booking Preferences

\begin{tabular}{|l|c|c|c|}
\hline \multicolumn{1}{|c|}{ Most preferred while booking a hotel } & Frequency & $\%$ & Rank \\
\hline Excellent rating on TripAdvisor & 8 & $20 \%$ & 2 \\
\hline Environmentally certified & 6 & $15 \%$ & 3 \\
\hline Using organic products & 18 & $45 \%$ & 1 \\
\hline Discounts and promotions & 8 & $20 \%$ & 2 \\
\hline
\end{tabular}

Regarding preference in booking a hotel, $45 \%$ prefer a hotel that uses organic products. Excellent rating on Trip Advisor and discounts and promotions distantly follow with both having $20 \%$. The least preferred is environmentally certified hotel with $15 \%$.

Table 6 Green Practices

\begin{tabular}{|c|c|c|c|c|c|c|c|c|}
\hline Statement & SA & $\mathbf{A}$ & $\mathbf{N}$ & D & SD & $\begin{array}{l}\text { K-S } \\
\text { Value }\end{array}$ & $\chi^{2}$ & $\begin{array}{c}\text { p- } \\
\text { value }\end{array}$ \\
\hline $\begin{array}{l}\text { Hotels should provide } \\
\text { information about the } \\
\text { green practices they } \\
\text { engage in }\end{array}$ & $\begin{array}{c}33 \\
85.2 \%\end{array}$ & $\begin{array}{c}6 \\
15 \%\end{array}$ & $\begin{array}{c}1 \\
2.5 \%\end{array}$ & $\begin{array}{c}0 \\
0 \%\end{array}$ & $\begin{array}{c}0 \\
0 \%\end{array}$ & 0.320 & \multirow{6}{*}{65.229} & \multirow{6}{*}{.000} \\
\hline $\begin{array}{l}\text { Hotels should have energy- } \\
\text { efficient lights in sleeping } \\
\text { areas }\end{array}$ & $\begin{array}{c}16 \\
40 \%\end{array}$ & $\begin{array}{c}20 \\
50 \%\end{array}$ & $\begin{array}{c}4 \\
10 \%\end{array}$ & $\begin{array}{c}0 \\
0 \%\end{array}$ & $\begin{array}{c}0 \\
0 \%\end{array}$ & 0.287 & & \\
\hline $\begin{array}{l}\text { Hotels should have low } \\
\text { flow toilets }\end{array}$ & $\begin{array}{c}13 \\
32 \%\end{array}$ & $\begin{array}{c}18 \\
45 \%\end{array}$ & $\begin{array}{c}6 \\
15 \%\end{array}$ & $\begin{array}{c}3 \\
7.5 \%\end{array}$ & $\begin{array}{c}0 \\
0 \%\end{array}$ & 0.268 & & \\
\hline $\begin{array}{l}\text { Hotels should have key } \\
\text { cards to turn the power of } \\
\text { the room }\end{array}$ & $\begin{array}{c}17 \\
42.5 \%\end{array}$ & $\begin{array}{c}15 \\
37.5 \%\end{array}$ & $\begin{array}{c}5 \\
12.5 \%\end{array}$ & $\begin{array}{c}1 \\
2.5 \%\end{array}$ & $\begin{array}{c}2 \\
5 \%\end{array}$ & 0.273 & & \\
\hline $\begin{array}{l}\text { Hotels should have } \\
\text { recycling bins }\end{array}$ & $\begin{array}{c}17 \\
42.5 \% \\
\end{array}$ & $\begin{array}{c}13 \\
32.5 \% \\
\end{array}$ & $\begin{array}{c}6 \\
15 \% \\
\end{array}$ & $\begin{array}{c}1 \\
2.5 \% \\
\end{array}$ & $\begin{array}{c}3 \\
7.5 \% \\
\end{array}$ & 0.267 & & \\
\hline $\begin{array}{l}\text { Hotels should have sheets } \\
\text { changed upon request only }\end{array}$ & $\begin{array}{c}15 \\
37.5 \%\end{array}$ & $\begin{array}{c}9 \\
22.5 \%\end{array}$ & $\begin{array}{c}13 \\
32 \%\end{array}$ & $\begin{array}{c}2 \\
5.0 \%\end{array}$ & $\begin{array}{c}1 \\
2.5 \%\end{array}$ & 0.258 & & \\
\hline
\end{tabular}




\begin{tabular}{|l|c|c|c|c|c|c|c|c|}
\hline $\begin{array}{l}\text { Hotels should have towel } \\
\text { re-use programs }\end{array}$ & 8 & 16 & 7 & 3 & 6 & 0.228 & & \\
\hline
\end{tabular}

Null hypothesis.1: There is no relationship between Green Practices and the choice of the respondents.

From Table 6, it can be seen that the p-value is less than .05. So, the null hypothesis gets rejected. Therefore, there is a significant relationship between Green Practices and the choices of the respondents. Now comparing the K-S values obtained from the Kolmogorov-Smirnov test, 'Hotels should provide information about the green practices they engage in' (.320) ranked first, followed by 'Hotels should have energy-efficient lights bulbs in sleeping areas' (.287) and 'Hotels should have key cards to turn the power of the room' (.273).

Table 7 Green Hotels

\begin{tabular}{|c|c|c|c|c|c|c|c|c|}
\hline Statement & SA & $\mathbf{A}$ & $\mathbf{N}$ & D & SD & $\begin{array}{c}\text { K-S } \\
\text { Value }\end{array}$ & $\chi^{2}$ & $\begin{array}{c}\text { p- } \\
\text { value }\end{array}$ \\
\hline $\begin{array}{l}\text { It is worth paying } \\
\text { premium price to stay at } \\
\text { a hotel which engages } \\
\text { green practices }\end{array}$ & $\begin{array}{c}23 \\
57.5 \%\end{array}$ & $\begin{array}{c}7 \\
17.5 \%\end{array}$ & $\begin{array}{c}6 \\
15.0 \%\end{array}$ & $\begin{array}{c}4 \\
10.0 \%\end{array}$ & $\begin{array}{c}0 \\
0 \%\end{array}$ & 0.282 & \multirow{13}{*}{79.428} & \multirow{13}{*}{.003} \\
\hline $\begin{array}{l}\text { Green hotels provide } \\
\text { good value for money }\end{array}$ & $\begin{array}{c}15 \\
37.5 \% \\
\end{array}$ & $\begin{array}{c}17 \\
42.5 \% \\
\end{array}$ & $\begin{array}{c}7 \\
17.5 \% \\
\end{array}$ & $\begin{array}{c}1 \\
2.5 \% \\
\end{array}$ & $\begin{array}{c}0 \\
0 \%\end{array}$ & 0.277 & & \\
\hline $\begin{array}{l}\text { Green hotels pricing is } \\
\text { reasonable and } \\
\text { affordable }\end{array}$ & $\begin{array}{c}11 \\
27.5 \%\end{array}$ & $\begin{array}{c}18 \\
45.0 \%\end{array}$ & $\begin{array}{c}7 \\
17.5 \%\end{array}$ & $\begin{array}{c}4 \\
10.0 \%\end{array}$ & $\begin{array}{c}0 \\
0 \%\end{array}$ & 0.260 & & \\
\hline $\begin{array}{l}\text { Green hotels provide } \\
\text { good service quality }\end{array}$ & $\begin{array}{c}9 \\
22.5 \% \\
\end{array}$ & $\begin{array}{c}18 \\
45.0 \% \\
\end{array}$ & $\begin{array}{c}13 \\
32.5 \% \\
\end{array}$ & $\begin{array}{c}0 \\
0 \% \\
\end{array}$ & $\begin{array}{c}0 \\
0 \% \\
\end{array}$ & 0.260 & & \\
\hline $\begin{array}{l}\text { I encourage my family to } \\
\text { stay at green hotels when } \\
\text { traveling }\end{array}$ & $\begin{array}{c}7 \\
17.5 \%\end{array}$ & $\begin{array}{c}17 \\
42.5 \%\end{array}$ & $\begin{array}{c}15 \\
37.5 \%\end{array}$ & $\begin{array}{c}1 \\
2.5 \%\end{array}$ & $\begin{array}{c}0 \\
0 \%\end{array}$ & 0.250 & & \\
\hline $\begin{array}{l}\text { I rarely plan to stay at } \\
\text { green hotels when I travel }\end{array}$ & $\begin{array}{c}10 \\
25.0 \%\end{array}$ & $\begin{array}{c}15 \\
37.5 \% \\
\end{array}$ & $\begin{array}{c}10 \\
25.0 \%\end{array}$ & $\begin{array}{c}4 \\
10.0 \% \\
\end{array}$ & $\begin{array}{c}1 \\
2.5 \%\end{array}$ & 0.248 & & \\
\hline $\begin{array}{l}\text { Green hotels offer } \\
\text { healthy meals }\end{array}$ & $\begin{array}{c}12 \\
30.0 \% \\
\end{array}$ & $\begin{array}{c}21 \\
52.5 \% \\
\end{array}$ & $\begin{array}{c}4 \\
10.0 \% \\
\end{array}$ & $\begin{array}{c}3 \\
7.5 \% \\
\end{array}$ & $\begin{array}{c}0 \\
0 \% \\
\end{array}$ & 0.270 & & \\
\hline $\begin{array}{l}\text { I believe it is good to } \\
\text { contribute to the } \\
\text { environmental protection } \\
\text { and sustainable } \\
\text { development }\end{array}$ & $\begin{array}{c}13 \\
32.5 \%\end{array}$ & $\begin{array}{c}17 \\
42.5 \%\end{array}$ & $\begin{array}{c}5 \\
12.5 \%\end{array}$ & $\begin{array}{c}5 \\
12.5 \%\end{array}$ & $\begin{array}{c}0 \\
0 \%\end{array}$ & 0.263 & & \\
\hline $\begin{array}{l}\text { I have resources, time, } \\
\text { and opportunities to stay } \\
\text { at a green hotel when } \\
\text { traveling/ holiday }\end{array}$ & $\begin{array}{c}13 \\
32.5 \%\end{array}$ & $\begin{array}{c}19 \\
47.5 \%\end{array}$ & $\begin{array}{l}3 \\
7.5 \%\end{array}$ & $\begin{array}{l}3 \\
7.5 \%\end{array}$ & $\begin{array}{l}2 \\
7.5 \%\end{array}$ & 0.263 & & \\
\hline $\begin{array}{l}\text { Staying at a green hotel is } \\
\text { expensive }\end{array}$ & 19 & $\begin{array}{c}13 \\
32.5 \% \\
\end{array}$ & $\begin{array}{c}3 \\
7.5 \% \\
\end{array}$ & $\begin{array}{c}3 \\
7.5 \%\end{array}$ & $\begin{array}{c}2 \\
7.5 \%\end{array}$ & 0.273 & & \\
\hline $\begin{array}{l}\text { Finding a green hotel } \\
\text { when travelling takes } \\
\text { time and effort }\end{array}$ & $\begin{array}{c}13 \\
32.5 \%\end{array}$ & $\begin{array}{c}14 \\
35.0 \%\end{array}$ & $\begin{array}{c}10 \\
25.0 \%\end{array}$ & $\begin{array}{c}1 \\
2.5 \%\end{array}$ & $\begin{array}{l}2 \\
7.5 \%\end{array}$ & 0.258 & & \\
\hline $\begin{array}{l}\text { Location of a green hotel } \\
\text { needs to be convenient }\end{array}$ & 23 & $\begin{array}{c}9 \\
22.5 \% \\
\end{array}$ & $\begin{array}{c}6 \\
15.0 \% \\
\end{array}$ & $\begin{array}{c}1 \\
2.5 \% \\
\end{array}$ & $\begin{array}{c}1 \\
2.5 \% \\
\end{array}$ & 0.287 & & \\
\hline $\begin{array}{l}\text { My budget encourage me } \\
\text { to stay at a certain hotel }\end{array}$ & $\begin{array}{c}13 \\
32.5 \% \\
\end{array}$ & 16 & $\begin{array}{c}7 \\
17.5 \% \\
\end{array}$ & $\begin{array}{c}3 \\
7.5 \% \\
\end{array}$ & $\begin{array}{c}1 \\
2.5 \% \\
\end{array}$ & 0.262 & & \\
\hline
\end{tabular}

Null hypothesis.2: There is no relationship between Green Hotels and the choice of the respondents.

From Table 7, it can be seen that the p-value is less than .05. So, the null hypothesis gets rejected. Therefore, there is a significant relationship between Green Hotels and the choices of the respondents. Now comparing the K-S values obtained from the Kolmogorov-Smirnov test, 'Location of a green hotel needs to be convenient' (.287) ranked first, followed by 'It is worth paying a premium price to stay at a hotel which 
engages green practices' (.282) ranked second; 'Green hotels provide good value for money (.277) ranked third; 'Staying at a green hotel is expensive' (.273) ranked fourth; 'Green hotels offer healthy meals' (.270) ranked fifth and ' $\mathrm{I}$ believe it is good to contribute to the environmental protection and sustainable development' $(.263)$ ranked sixth.

\section{Qualitative Analysis}

The Researcher had interviews with senior persons and the summary of the interviews are as follows:

\begin{tabular}{|c|c|c|}
\hline \# & Question & Answers \\
\hline 1 & Sustainable Initiatives & $\begin{array}{l}\text { 1. Water-saving: under practiced as low-flow showerheads and } \\
\text { faucets have been already installed. } \\
\text { 2. Low energy consumption - Low energy-saving lights } \\
\text { already installed in the hotel. Also kitchen and laundry } \\
\text { equipment with automated power management systems. } \\
\text { 3. Towels re-use - guests are educated to re-use towels through } \\
\text { a request to hang them if they wish to re-use and place them on } \\
\text { the bathroom floor if they wish to be changed - thereby } \\
\text { reducing the chemicals. (Assistant Manager) }\end{array}$ \\
\hline 2 & Other initiatives & $\begin{array}{l}\text { Customizing sustainable programs, environmental } \\
\text { performance, and low-cost initiatives }\end{array}$ \\
\hline 3 & $\begin{array}{l}\text { Main reasons for adopting } \\
\text { sustainable practices }\end{array}$ & $\begin{array}{l}\text { The main reason is its functional impact on the business. It is } \\
\text { also good for the environment which for them is equally } \\
\text { important. (HR Manager) }\end{array}$ \\
\hline 4 & Challenges/issues faced & $\begin{array}{l}\text { 1. Not all the guests are aware of the hotel sustainability } \\
\text { initiatives. However, it is exciting to see some guests are taking } \\
\text { the initiative and participating in the practices once they see the } \\
\text { messages of the hotel. } \\
\text { 2. Engaging with local communities by getting fruits and } \\
\text { vegetables is itself a challenge because most of the global chain } \\
\text { hotels always depend on supply from the local farmers rather } \\
\text { than buying from the supermarkets. }\end{array}$ \\
\hline 5 & $\begin{array}{l}\text { The steps are taken to } \\
\text { overcome } \\
\text { issues/challenges }\end{array}$ & $\begin{array}{l}\text { 3. By enforcing clear instructions to staff to practice the } \\
\text { initiatives through training, courses, and briefings. Guests find } \\
\text { the instructions and messages across the hotel. } \\
\text { 4. A message is available on the website to all guests browsing } \\
\text { the website. This is in addition to messages in the rooms to } \\
\text { educate the guests about environmentally sustainable practices. }\end{array}$ \\
\hline 6 & Willingness to pay extra & $\begin{array}{l}\text { Customers are ready to pay higher prices for green products in } \\
\text { the hotel, i.e. for a greener stay. }\end{array}$ \\
\hline 7 & Any other suggestions & $\begin{array}{l}\text { 1.It is essential to create awareness of the greener environment } \\
\text { scheme as the initiatives have an effective impact on cost } \\
\text { savings. } \\
\text { 2. The initiatives help to reduce resource wastage. Awareness } \\
\text { within the community is raised through education and training. } \\
\text { 3.employees/staff need to be educated through special training } \\
\text { to increase awareness with instructions such as switching off } \\
\text { computers and unnecessary lights after duty, etc. }\end{array}$ \\
\hline
\end{tabular}

\section{Discussion \& Conclusion}

Summarising the results of the quantitative analyses, the following findings were observed:

- Among the environmentally friendly hotel factors, the majority of the respondents declared that communication of sustainability practices topped the list whereas the energy conservation facts came next such as the usage of local products and suppliers and water-efficient appliances.

- Among the environmentally friendly initiatives identified by the guests, the hotel's recycling program emerged as their first choice, followed by energy-efficient light bulbs, energy star appliances, watersaving fixtures, and a linen re-use program.

- The majority of the respondents agreed that sustainable practices in hotels play a significant role in providing excellent services and products. 
- Among the preference in booking a hotel, most of the respondents reported that the guests preferred a hotel that uses organic products followed by the rating on Trip Advisor, Discounts and promotions whereas only a few guests reported that the preference of environmentally certified hotel.

- Among the green practices, it was reported that the guests preferred 'hotels should provide information about the green practices they engage in' ranked first, followed by 'Hotels should have energy-efficient lights bulbs in sleeping areas' and 'Hotels should have key cards to turn the power of the room'.

- Among the green hotel factors, it was reported that 'the location of a green hotel needs to be convenient ranked first, followed by 'It is worth paying a premium price to stay at a hotel which engages green practices' and 'Green hotels provide good value for money.

The results from the interview show that chain hotels have started to focus intensely on adopting a variety of sustainable practices by using advanced technology which could save the environment and the cost alike. However, not all guests are aware of the hotel sustainability initiatives. Hoteliers noticed that some guests reading the messages in the hotel about the sustainability initiatives. As a result, it is necessary to educate hotel guests about sustainable initiatives. Oliveira et al. (2016) confirmed that raising the awareness of guests and employees will make a positive impact on the hotel sustainably and environmentally friendly. Also as Rosa and Silva (2017) assured that it is always necessary and advisable to represent comfort hospitality.

To conclude, it is very important to understand and aware of the greener environment schemes. Hotel sustainability initiatives have indeed effectively impacted cost savings. It helps to reduce waste, and resource wastage. This is similar to the findings of Rakická (2016) who mentioned that the hotel industry in developed countries concentrating more on the reduction of costs and sustainable practices. Awareness within the community can be raised only through proper education and training. It is also being observed that most of the chain hotels nowadays are relying on sustainable practices which hem help save cost-cutting and most importantly, enable guests to view the hotel as environmentally friendly. With advanced technology, chain hotels can control the cost-saving measures can be enhanced and it can also be ensured that the guests are satisfied with such innovation which make them happier and make their trips and stay a memorable one.

\section{Recommendations}

The researcher recommends the two hotels to be more environmentally conscious with different sustainable practices, as it would attract a massive number of guests gaining a new experience in the hotels. Also, it is recommended to educate the employees and create awareness of such sustainable practices adopted by the hotels. Consequently, this sort of awareness will enable the two hotels to overcome the challenges faced by them. In addition to that, the researcher recommends the hotel managers' implementation of sustainable practices in the two hotels will help them to retain their brands.

Further, collaboration with the colleges specialized in hospitality such as Oman Tourism College and hospitality institutes can be involved through employing the students as interns or for special training purposes so that they can be of better help to these hotels soon. As the Omani youth are ready to face challenges, fresh graduates from these colleges can be enrolled through job fairs, internships, etc.

\section{References}

1. Aaker, D. A. (1996). Measuring brand equity across products and markets. California management review, 38(3). https://doi.org/http://doi.org/https://doi.org/10.2307/41165845

2. Bagur-Femenias, L., Celma, D., \& Patau, J. (2016). The adoption of environmental practices in small hotels. voluntary or mandatory? An empirical approach. Sustainability, 8(7), 14. https://doi.org/https://doi.org/10.3390/su8070695

3. Berezan, O., Millar, M., \& Raab, C. (2010, Jun.8, 2010). Hotel guests' perceptions of sustainable hotel practices in a Mexican destination Caesars Hospitality Research Summit. 9, University of Nevada, Las Vegas. https://digitalscholarship.unlv.edu/hhrc/2010/june2010/9

4. Brammer, S., Jackson, G., \& Matten, D. (2012). Corporate social responsibility and institutional theory: New perspectives on private governance. Socio-economic Review, 10(1), 3-28. https://doi.org/https://doi.org/10.1093/ser/mwr030

5. Bruns-Smith, A., Choy, V., Chong, H., \& Verma, R. (2015). Environmental sustainability in the hospitality industry: Best practices, guest participation, and customer satisfaction. School of Hotel Administration Cornell University. https://ecommons.cornell.edu/bitstream/handle/1813/71174/BrunsSmith_2015_Enviro_Sustain.pdf?se quence $=1 \&$ is Allowed $=\mathrm{y}$ 
6. Bukva, M. (2009). Sustainable Development Plan 2010 14. Retrieved 25th April 2021, from https://www.scribd.com/document/56332693/Sustainable-Development-Plan-2010-Clarion-CongressHotel-Prague

7. Butler Rosebury \& Partners Architects. (2016, Oct. 24, 2016). [Video]. BRP Architects. https://www.youtube.com/watch?v=dImBq3Ungns

8. Chan, E. S. (2013). Gap analysis of green hotel marketing. International Journal of Contemporary Hospitality Management, 25(7), 1017-1048. https://doi.org/https://doi.org/10.1108/IJCHM-09-2012$\underline{0156}$

9. Chan, E. S., \& Hawkins, R. (2010). Attitude towards EMSs in an international hotel: An exploratory case study. International Journal of Hospitality Management, 29(4), 641-651. https://doi.org/https://doi.org/10.1016/j.ijhm.2009.12.002

10. Chan, W. W. (2009). Environmental measures for hotels' environmental management systems: ISO 14001. International Journal of Contemporary Hospitality Management, 21(5), 542-560. https://doi.org/https://doi.org/10.1108/09596110910967791

11. Chikita, M. (2012). Analyzing the impact on consumer satisfaction, behavior, and attitudes by using ecofriendly practices and products in Surfers Paradise/Gold Coast city hotels, Australia [Bachelor Thesis, HAAGA-HELIA University of Applied Sciences]. Helsinki.

12. De Grosbois, D. (2012). Corporate social responsibility reporting by the global hotel industry: Commitment, initiatives, and performance. International Journal of Hospitality Management, 31(3), 896-905. https://doi.org/https://doi.org/10.1016/j.ijhm.2011.10.008

13. DiPietro, R. B., \& Wang, Y. R. (2010). Key issues for ICT applications: impacts and implications for hospitality operations. Worldwide Hospitality and Tourism Themes, 2(1), 49-67. https://doi.org/https://doi.org/10.1108/17554211011012595

14. Foster, S. T., Sampson, S. E., \& Dunn, S. C. (2000). The impact of customer contact on environmental initiatives for service firms. International Journal of Operations \& Production Management, 20(2), 187 203. https://doi.org/https://doi.org/10.1108/01443570010304251

15. Grant, D. B., Wong, C. Y., \& Trautrims, A. (2017). Sustainable logistics and supply chain management: principles and practices for sustainable operations and management (Second ed.). Kogan Page Publishers.

16. Grover, A. (2014). Importance of CSR in Inclusive development. Procedia-Social and Behavioral Sciences, 157, 103-108. https://doi.org/https://doi.org/10.1016/j.sbspro.2014.11.013

17. Heesbeen, L. (2014). Corporate Social Responsibility: A Case Study of Scandic Hotels [Bachelor Thesis, HAAGA-HELIA University of Applied Sciences].

18. Hitchcock, D. E., Willard, M. L., \& Willard, M. (2009). The business guide to sustainability: Practical strategies and tools for organizations. Earthscan.

19. Holden, A. (2016). Environment and tourism. Routledge.

20. Jain, S. K., \& Kaur, G. (2004). Green marketing: An attitudinal and behavioural analysis of Indian $\begin{array}{llll}\text { consumers. } & \text { Global }\end{array}$ https://doi.org/https://doi.org/10.1177/097215090400500203

21. Järvensivu, J. (2014). Sustainability in Hotel Facilities: A Case Study: Original Sokos Hotel Villa [Bachelor's Thesis, JAMK University of Applied Sciences]. http://urn.fi/URN:NBN:fi:amk2014061112635

22. Jayawardena, C. C., Pollard, A., Caira, R., Sovani, A., \& Willie, P. (2013). The Canadian hotel industry: a roundtable discussion on challenges and trends. Worldwide Hospitality and Tourism Themes, 5(2), 114-131. https://doi.org/https://doi.org/10.1108/17554211311314092

23. Jayawardena, C. C., Pollard, A., Chort, V., Choi, C., \& Kibicho, W. (2013). Trends and sustainability in the Canadian tourism and hospitality industry. Worldwide Hospitality and Tourism Themes, 5(2), 132150. https://doi.org/https://doi.org/10.1108/17554211311314164

24. Jones, P., Hillier, D., \& Comfort, D. (2014). Sustainability in the global hotel industry. International Journal of Contemporary Hospitality Management. https://doi.org/https://doi.org/10.1108/IJCHM-102012-0180

25. Katrandjiev, H. (2016). Ecological marketing, green marketing, sustainable marketing: synonyms or an evolution of ideas. Economic Alternatives, 1(7), 71-82.

26. Kleinrichert, D., Ergul, M., Johnson, C., \& Uydaci, M. (2012). Boutique hotels: Technology, social media and green practices. Journal of Hospitality and Tourism Technology, 3(3), 211-225. https://doi.org/https://doi.org/10.1108/17579881211264495 
27. Korjala, V. (2012). Cultural diversity in hospitality management: how to improve cultural diversity workforce [Bachelor Thesis, Turku University of Applied Sciences]. https://www.theseus.fi/bitstream/handle/10024/55331/Korjala_Veera.pdf?sequence=1\&isAllowed=y

28. Legrand, W., Sloan, P., \& Chen, J. S. (2016). Sustainability in the hospitality industry: Principles of sustainable operations. Routledge.

29. Leonidou, L. C., Leonidou, C. N., Fotiadis, T. A., \& Zeriti, A. (2013). Resources and capabilities as drivers of hotel environmental marketing strategy: Implications for competitive advantage and performance. Tourism Management, $\quad$ 35, 94-110. https://doi.org/https://doi.org/10.1016/j.tourman.2012.06.003

30. Lorenc, M. (2016). Corporate Social Responsibility in the Hospitality Industry: A qualitative study on the perception of CSR and its activities [Masters' Thesis, Aalborg University]. Denmark.

31. Lunkes, R. J., \& Rosa, F. (2012). Gestão hoteleira: custos, sistemas de informação, planejamento estratégico, orçamento e gestão ambiental. Curitiba: Juruá, 1, 276.

32. Luo, X., \& Bhattacharya, C. B. (2006). Corporate social responsibility, customer satisfaction, and market value. Journal of Marketing, 70(4), 1-18. https://doi.org/https://doi.org/10.1509/jmkg.70.4.001

33. Manaktola, K., \& Jauhari, V. (2007). Exploring consumer attitude and behaviour towards green practices in the lodging industry in India. International Journal of Contemporary Hospitality Management, 19(5), 364-377. https://doi.org/https://doi.org/10.1108/09596110710757534

34. Marriott. (2015). Business Model and Sustainability Strategy M. International. https://www.marriott.com/marriottassets/Multimedia/PDF/CorporateResponsibility/serve360/2015_Bu sinessModelandSustainabilityStrategy.pdf

35. Middleton, V. T., \& Hawkins, R. (1998). Sustainable tourism: A marketing perspective. Routledge.

36. Ogbeide, G.-C. (2012). Perception of green hotels in the 21 st century. Journal of Tourism Insights, 3(1), 1-10. https://doi.org/https://doi.org/10.9707/2328-0824.1032

37. Oliveira, J. P., Tricárico, L. T., Varella, B. G., \& Velasquez, G. G. (2016). Arquitetura hoteleira sob a ótica da sustentabilidade e da hospitalidade do espaço: um estudo sobre a aplicação dos conceitos de sustentabilidade e hospitalidade do espaço em projetos de hotéis

38. (Hotel architecture from the perspective of sustainability and space hospitality: a study on the application of the concepts of sustainability and hospitality space in hotel projects). Revista Brasileira de Pesquisa em Turismo, 10(1), 189-209. https://doi.org/https://doi.org/10.7784/rbtur.v10i1.993

39. Peattie, K. (2001). Towards sustainability: the third age of green marketing. The marketing review, 2(2), 129-146. https://doi.org/https://doi.org/10.1362/1469347012569869

40. Pickett-Baker, J., \& Ozaki, R. (2008). Pro-environmental products: marketing influence on consumer purchase decision. Journal of consumer marketing, 25(5), 281-293. https://doi.org/https://doi.org/10.1108/07363760810890516

41. Rahman, I., Reynolds, D., \& Svaren, S. (2012). How “green” are North American hotels? An exploration of low-cost adoption practices. International Journal of Hospitality Management, 31(3), 720-727. https://doi.org/https://doi.org/10.1016/j.ijhm.2011.09.008

42. Rakická, M. (2016). Sustainable Practices of the Hotel Industry in Developing Countries [Bachelor Thesis, State University of New York - Empire State College].

43. Revilla, G., Dodd, T. H., \& Hoover, L. C. (2001). Environmental tactics used by hotel companies in Mexico. International Journal of Hospitality \& Tourism Administration, 1(3-4), 111-127. https://doi.org/https://doi.org/10.1300/J149v01n03 07

44. Rosa, F. S. d., \& Silva, L. C. (2017). Environmental sustainability in hotels, theoretical and methodological contribution. Revista Brasileira de Pesquisa em Turismo, 11(1), 39-60. https://doi.org/https://doi.org/10.7784/rbtur.v11i1.1161

45. Seibert, S. E., Kraimer, M. L., \& Crant, J. M. (2001). What do proactive people do? A longitudinal model linking proactive personality and career success. Personnel Psychology, 54(4), 845-874. https://doi.org/https://doi.org/10.1111/j.1744-6570.2001.tb00234.X

46. Siguaw, J. A., Enz, C. A., \& Namasivayam, K. (2000). Adoption of information technology in US hotels: strategically driven objectives. Journal of Travel Research, 39(2), 192-201. https://doi.org/https://doi.org/10.1177/004728750003900209

47. Stewart, R. A., Mohamed, S., \& Marosszeky, M. (2004). An empirical investigation into the link between information technology implementation barriers and coping strategies in the Australian construction

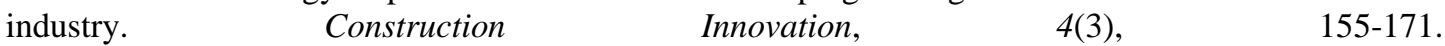
https://doi.org/https://doi.org/10.1108/14714170410815079

48. The Canadian Tourism Research Institute, \& The Conference Board of Canada. (2012). The Future of Canada's Tourism Sector: Shortages to Resurface as Labour Markets Tighten [Report]. The Canadian Tourism Human Resource Council. http://m3.ithq.qc.ca/collection/00000231.pdf 
49. Tuppen, H. (2013, Jan 30, 2013). Green Globe Certification connects with Green Hotelier. Green Globe. Retrieved Apr 28, 2021, from https://greenglobe.com/latest-news/green-globe-certification-connectswith-green-hotelier/

50. Van Rheede, A., \& Blomme, R. J. (2012). Sustainable practices in hospitality: A research framework. In Advances in hospitality and leisure (Vol. 8, pp. 257-271). Emerald Group Publishing Limited. https://doi.org/https://doi.org/10.1108/S1745-3542(2012)0000008018

51. Visser, W. (2008). Corporate social responsibility in developing countries. In The Oxford handbook of corporate social responsibility.

52. WANG, J.-Z., \& Jing, W. (2009). Issues, challenges, and trends, that facing hospitality industry. Management Science and Engineering, 33-58. https://doi.org/http://dx.doi.org/10.3968/j.mse.1913035X20090304.006

53. Wheelen, T. L., \& Hunger, J. D. (1998). Strategic Management and Business Policy: entering 21st century global society. Prentice-Hall International.

54. WTO, \& UNDP. (2017). Tourism and the Sustainable Development Goals - Journey to 2030. UNWTO Madrid. file:///C:/Users/fkhan/Downloads/UNWTO_UNDP_Tourism\%20and\%20the\%20SDGs.pdf

55. y Patiño, M. G., Medina, F. X., \& Arilla, J. M. P. (2016). New trends in tourism? From globalization to postmodernism. International Journal of Scientific Management and Tourism, 2(3), 417-433.

56. Yadav, R., Dokania, A. K., \& Pathak, G. S. (2016). The influence of green marketing functions in building corporate image: Evidences from hospitality industry in a developing nation. International Journal of Contemporary Hospitality Management, 28(10), 2178-2196. https://doi.org/https://doi.org/10.1108/IJCHM-05-2015-0233

57. Zurburg, R., Ruff, D., \& Ninemeier, J. (1995). Environmental action in the United States lodging industry. Hospitality \& Tourism https://doi.org/https://doi.org/10.1080/23298758.1995.10685658

Copyright: () 2021 by the authors. Licensee Global Scientific Publications, Oman.

This work is licensed under a Creative Commons Attribution-ShareAlike 4.0 International License.

This is an open-access journal and the articles published in this journal are distributed under the terms of CC-BY-SA. 